\title{
The diversity of gas vesicle genes in Planktothrix rubescens from Lake Zürich
}

\author{
S. J. Beard, B. A. Handley, P. K. Hayes and A. E. Walsby \\ Author for correspondence: A. E. Walsby. e-mail: A. E.Walsby@bristol.ac.uk
}

School of Biological Sciences, University of Bristol, Woodland Road, Bristol BS8 1UG, UK

\begin{abstract}
Part of the gas vesicle gene cluster was amplified by PCR from three strains of Planktothrix rubescens isolated from Lake Zürich, Switzerland. Each contains multiple alternating copies of gvpA and gvpC. All of the gvpA sequences in the different strains are identical. There are two types of gvpC: gvp $^{20}$, of length $516 \mathrm{bp}$, encodes a $20 \mathrm{kDa}$ protein of 172 amino acid residues (whose $\mathbf{N}$-terminal amino acid sequence is homologous with the sequence of GvpC in Planktothrix [Oscillatoria] agardhii); gvpC ${ }^{16}$, of length $417 \mathrm{bp}$, encodes a $16 \mathrm{kDa}$ protein of 139 amino acid residues that differs in lacking an internal 33-residue section. An untranslated 72 bp fragment from the $3^{\prime}$ end of gvpC, designated $\Omega C$, is also present in some strains. The two types of gvpC and presence of $\Omega C$ could be distinguished by the different lengths of PCR amplification products obtained using pairs of oligonucleotide primers homologous to internal sequences in gvpC and gvpA. Three genotype classes were found: GV1, containing only $\mathrm{gvpC}^{20} ; \mathrm{GV2}$, containing $\mathrm{gvpC}^{20}$ and $\Omega C_{\text {; }}$ and $\mathrm{GV3}$, containing $\operatorname{gvpC}^{16}, \operatorname{gvpC}^{20}$ and $\Omega C$. Subclasses of GV2 and GV3 contained either one or two copies of $\Omega C$. The accompanying paper by D. I. Bright \& A. E. Walsby (Microbiology 145, 2769-2775) shows that strains of the GV3 genotype produce gas vesicles with a higher critical pressure than those of GV1 and GV2. A PCR survey of 185 clonal cultures of $P$. rubescens isolated from Lake Zürich revealed that 3 isolates were of genotype GV1, 73 were of GV2 and 109 were of GV3. The PCR technique was used to distinguish the gas vesicle genotype, and thence the associated critical-pressure phenotype, of single filaments selected from lakewater samples. Sequence analysis of the 16S rDNA and of regions within the operons encoding phycoerythrin, phycocyanin and Rubisco confirmed that these strains of Planktothrix form a tight phylogenetic group.
\end{abstract}

Keywords: cyanobacterial genetics, gas vesicles, Planktothrix rubescens

\section{INTRODUCTION}

Many deep lakes in temperate latitudes contain populations of the red-coloured planktonic cyanobacterium Planktothrix rubescens, which forms layers in the metalimnion during the summer period of thermal stratification. After winter mixing, these cyanobacteria float back up to the metalimnion using the buoyancy provided by their gas vesicles. A gas vesicle collapses when exposed to a certain pressure termed its critical

Abbreviations: 33RR, 33-residue repeat; $p_{c^{\prime}}$ critical pressure; Rubisco, ribulose-1,5-bisphosphate carboxylase/oxygenase.

The EMBL accession numbers for the sequences determined in this work are listed in Table 5. pressure $\left(p_{\mathrm{c}}\right)$. For mechanical reasons $p_{\mathrm{c}}$ varies inversely with the gas vesicle's width (Walsby, 1982, 1991). In cyanobacteria from deep lakes there has been selection for narrower and stronger gas vesicles, which withstand the high hydrostatic pressure experienced when the organisms are mixed down to great depths (Walsby, 1994).

Differences in the $p_{\mathrm{c}}$ values of gas vesicles have been found in several strains of Planktothrix rubescens isolated from Lake Zürich, in Switzerland, and it has been commented that the proportions of the different strains in the population will change according to the depth of winter mixing each year (Walsby et al., 1998). We describe here variations in gas vesicle genes of Planktothrix that are correlated with variations in the $p_{\mathrm{c}}$ 
of gas vesicles and can be used in studies of the natural selection of gas vesicle width.

Gas vesicles are hollow structures formed from two types of protein. GvpA is a small hydrophobic protein arranged along ribs that form the cylindrical structure and its conical end caps. The amino acid sequence of GvpA is highly conserved (Griffiths et al., 1992). In Pseudanabaena there is only one copy of the gene that encodes GvpA (Damerval et al., 1991) but in Calothrix sp. there are two identical gvpA genes (Damerval et al., 1987) and in Anabaena flos-aquae there are at least five gupAs in tandem repeat (Hayes \& Powell, 1995).

GvpC is a larger hydrophilic protein; it is located on the outside of the structure (Walsby \& Hayes, 1988) and is thought to tie the ribs together. It varies in size in different cyanobacteria and its amino acid sequence is much less conserved (Griffiths et al., 1992). In Calothrix sp. the single $g v p C$ gene contains four contiguous semiconserved repeats of $99 \mathrm{nt}$, which encode four 33residue repeats (33RRs) within the 162 amino acid residue protein (Damerval et al., 1987). In Anabaena flos-aquae the single gvpC encodes a 193 residue protein, with five 33RRs (Hayes et al., 1988). The $\mathrm{N}$-terminal sequences obtained from other cyanobacteria are too short to reveal if 33RRs are present. In the halophile Dactylococcopsis salina there are two GvpCs, of 17 and $35 \mathrm{kDa}$, in which, peculiarly, the first 24 residues are identical but subsequent sequences are not (Griffiths et al., 1992). GvpCs in halobacteria show little sequence similarity with those in cyanobacteria, though they contain seven partially conserved repeats of 32-41 residues (Horne et al., 1991; Jones et al., 1991).

GvpC stabilizes the gas vesicle: the $p_{c}$ decreases when GvpC is removed (Walsby \& Hayes, 1988) but returns to its original value when the protein is replaced (Hayes et al., 1992). Kinsman et al. (1995) made recombinant GvpCs with two, three, four or five of the 33RRs and found that their effectiveness in strengthening the structure increased with the number of repeats. GvpC may also determine the width of gas vesicles, which affects also their $p_{c}$. Gas vesicles grow from a biconical structure (Waaland \& Branton, 1969; Lehmann \& Jost, 1971), probably with the addition of new GvpA molecules at the middle of the structure where the cones contact one another (Walsby, 1994). After reaching a certain diameter the central portion extends as a cylinder. GvpC, which is distributed over the entire surface, must be attached to the ribs in the cones, as well as the cylinder, as the structure is assembled (Buchholz et al., 1993). GvpC may, therefore, influence the transition from cone to cylinder, and hence control the final cylinder-diameter of the mature structure. In halobacteria mutations to $g \nu p C$ cause changes in the shape of the gas vesicles that form (Offner et al., 1996; DasSarma et al., 1994).

We report here the occurrence in Planktothrix rubescens, isolated from Lake Zürich (Walsby et al., 1998), of two or more repeats of an alternating $g v p A-g v p C$ gene cluster that shows variation in the size of the $g v p C$ gene. Strains of a variant that contain a shortened form of $g v p C$, lacking a $99 \mathrm{nt}$ section, produce gas vesicles that have a higher $p_{\mathrm{c}}$ (Bright \& Walsby, 1999). We demonstrate that single filaments of these variants can be identified by PCR amplification using $g v p A$ - and $g v p C$-specific primers. This provides a means of determining the proportions of these variants in natural populations of the cyanobacterium, which can be used in making a quantitative study of the natural selection of gas vesicle strength.

\section{METHODS}

Clonal cultures of Planktothrix rubescens. The clonal cultures Pla 9303-9316 and 9401-9402 have been described previously (Walsby et al., 1998). Strain CYA 1 (Staub, 1961; Utkilen et al., 1985) was obtained from the Culture Collection of the Norwegian Institute for Water Research (NIVA), Oslo. Further cultures were established from single filaments isolated from samples taken from Lake Zürich in March, June, September and October 1997. Using a sterilized Terumo syringe under a dissecting microscope, single filaments were transferred through four drops of sterile growth medium and then to $5 \mathrm{ml}$ medium in a sterile tube. Cultures were incubated at $14-16^{\circ} \mathrm{C}$ in illuminated growth cabinets. For the first month the tubes were pressurized $(1.4 \mathrm{MPa})$ at weekly intervals to collapse gas vesicles and prevent loss of filaments floating into the drying meniscus. Subcultures were made from floating filaments to select against mutants lacking gas vesicles.

Isolation of genomic DNA from Planktothrix rubescens. After pressurizing (1.4 MPa) to collapse gas vesicles, filaments from $1-5 \mathrm{ml}$ of culture were centrifuged at $12000 \mathrm{~g}$ for $10 \mathrm{~min}$, washed in $100 \mathrm{mM}$ Tris, $20 \mathrm{mM}$ EDTA (pH 8.0) and resuspended in $200 \mu$ lof the same buffer. Lysozyme was added to $1 \mathrm{mg} \mathrm{ml}^{-1}$ and the suspension was incubated at $37^{\circ} \mathrm{C}$ for $2 \mathrm{~h}$ with occasional mixing. Proteinase $\mathrm{K}\left(200 \mu \mathrm{g} \mathrm{ml}^{-1}\right)$ was added and the suspension was incubated at $55^{\circ} \mathrm{C}$ for a further $2 \mathrm{~h}$. SDS was then added to $0 \cdot 1 \%(\mathrm{w} / \mathrm{v})$ and the cell lysate was extracted with an equal volume of phenol/chloroform/ isoamyl alcohol $(25: 24: 1$, by vol.) and then with chloroform/ isoamyl alcohol $(24: 1, \mathrm{v} / \mathrm{v})$. A $0 \cdot 1 \times$ volume of $3 \mathrm{M}$ sodium acetate $(\mathrm{pH} 7 \cdot 0)$ and an equal volume of 2-propanol were added to the final aqueous phase and nucleic acids were left to precipitate at room temperature for $12 \mathrm{~h}$. The precipitated DNA was collected by centrifugation, washed with $70 \%$ ethanol, vacuum-dried, and redissolved in $50 \mu \mathrm{l} 10 \mathrm{mM}$ Tris, 1 mM EDTA (pH 8.0).

PCR amplification, cloning and sequencing. Genomic DNA from the Planktothrix cultures was used as a template in PCR amplifications with the primers specific to various genes (Table 1). PCR amplification reactions $(50 \mu \mathrm{l})$ contained $0 \cdot 25-0.50 \mu \mathrm{g}$ genomic DNA, $1 \times$ SuperTaq buffer $(10 \mathrm{mM}$ Tris/ $\mathrm{HCl} \mathrm{pH} 9 \cdot 0,1.5 \mathrm{mM} \mathrm{MgCl}_{2}, 50 \mathrm{mM} \mathrm{KCl}, 0 \cdot 1 \%$ Triton $\mathrm{X}-100,0 \cdot 01 \%$ gelatin; H. T. Biotechnology), $1 \mu \mathrm{M}$ of each oligonucleotide primer, $200 \mu \mathrm{M}$ of deoxynucleotide triphosphates (Promega) and 1 unit SuperTaq DNA polymerase $(\mathrm{H}$. T. Biotechnology). The reactions were performed in an OmniGene thermal cycler (Hybaid). The reaction conditions for the principal PCR amplifications of the gene loci investigated are shown in Table 2. PCR products were analysed by agarose gel electrophoresis in $1 \times \mathrm{TAE}$ running buffer (Sambrook et al., 1989). PCR products were isolated from amplification reactions using the High Pure PCR Product 
Table 1. Oligonucleotide primers used for $P C R$ and sequence determination

Underlined regions indicate restriction sites introduced to facilitate cloning.

\begin{tabular}{|c|c|c|c|c|}
\hline \multirow[t]{2}{*}{ Primer } & \multirow[t]{2}{*}{ Sequence* $\left(5^{\prime}\right.$ to $\left.3^{\prime}\right)$} & \multirow[t]{2}{*}{ Direction $\uparrow$} & \multicolumn{2}{|r|}{ Target site } \\
\hline & & & Gene or & Position $\neq$ \\
\hline GVPA-5 & GCTCTAGAYMGIATYYTIGAYAARGG & $\mathrm{F}$ & $g v p A$ & 954-971 (AJ132357) \\
\hline GVPA-3' & CGGAATTCIGCRTAYTTIARRTAIGT & $\mathrm{R}$ & $g v p A$ & $1077-1060$ (AJ132357) \\
\hline GVPA1 & CGGGATCCTATCCATAGAAGCAAGAATCGTGATCG & $\mathrm{F}$ & $g v p A$ & 1014-1048 (AJ132357) \\
\hline GVPA2 & CGGGATCCGAAGCTCGATTCCAACGAGGGAAAC & $\mathrm{R}$ & $g v p A$ & 1021-997 (AJ132357) \\
\hline GVPA3 & GAGTTCTTTAGGCTAATCAT & $\mathrm{R}$ & $\begin{array}{c}g v p C-A \\
\text { spacer }\end{array}$ & $856-837 \quad(\mathrm{AJ} 132357)$ \\
\hline GVPA7 & ATGCACAACCCACTGACACGA & $\mathrm{F}$ & $\begin{array}{c}g \nu p A-C \\
\text { spacer }\end{array}$ & 217-237 (AJ132357) \\
\hline GVPC1 & TCGGAATTCCCCCAAACTGTCTGT & $\mathrm{R}$ & $g v p C$ & $693-670 \quad(\mathrm{AJ} 132357)$ \\
\hline GVPC4 & CTTCGAATTCCCGATATAGGGTT & $\mathrm{R}$ & $g v p C^{20}$ & 509-487 (AJ132357) \\
\hline GVPC5 & CAGGCTTCTGAATTCCGGGAAG & $\mathrm{F}$ & $g v p C$ & 368-389 (AJ132357) \\
\hline GVPC6 & CGGAATTCCCACCGACATYCTA & $\mathrm{F}$ & $g v p C$ & 684-704 (AJ132357) \\
\hline GVP $\Omega 2$ & AGCGGATCCCAAGCCATTCCC & $\mathrm{F}$ & $\begin{array}{c}\text { gvpA- } \Omega C \\
\text { spacer }\end{array}$ & 1019-1039 (AJ132358) \\
\hline GVP $\Omega 3$ & GGGAATGGCTTGGGATCCGCT & $\mathrm{R}$ & $\begin{array}{c}\text { gvpA- } \Omega C \\
\text { spacer }\end{array}$ & 1039-1019 (AJ132358) \\
\hline $\operatorname{PE} \beta \mathrm{F}$ & TAYCCTAACCGTCGYWTKGCTGC & $\mathrm{F}$ & cpeB & $612-634 \quad(X 04592)$ \\
\hline $\mathrm{PE} \alpha \mathrm{R}$ & GCRCGTTGRATRGAACCTTGTAC & $\mathrm{R}$ & среA & 1133-1111 (X04592) \\
\hline $\mathrm{PC} \beta \mathrm{F}$ & GGCTGCTTGTTTACGCGACA & $\mathrm{F}$ & $c p c B$ & $720-739 \quad(\mathrm{X} 05239)$ \\
\hline $\mathrm{PC} \alpha \mathrm{R}$ & CCAGTACCACCAGCAACTAA & $\mathrm{R}$ & $\operatorname{cpcA}$ & $1405-1386(\mathrm{X} 05239)$ \\
\hline $\mathrm{PC} \alpha \mathrm{R} 3$ & GTGACTTGACGGAGGTAGTA & $\mathrm{R}$ & $\operatorname{cpcA}$ & $648-629 \quad(\mathrm{AJ} 131820)$ \\
\hline CYARUB-5' & CGAMCTGTGGAARGAATTCAAGTT & $\mathrm{F}$ & $r b c L$ & $2100-2123(\mathrm{~J} 01540)$ \\
\hline CYARUB-3' & TGGGYTTGTRAACGATGAAGCTTA & $\mathrm{R}$ & $r b c S$ & 3018-2995 (J01540) \\
\hline CYANO-5' & CAGCTGCATGCAAGCTTAGAGTTTGATCCTGGCTCAG & $\mathrm{F}$ & $16 \mathrm{~S}$ rDNA & $1439-1458(\mathrm{X} 03538)$ \\
\hline CYANO-3' & CAGCTGTCGACGGATCCAAAGGAGGTGATCCAGCCGCA & $\mathrm{R}$ & $16 \mathrm{~S}$ rDNA & 2918-2898 (X03538) \\
\hline PLANKTO-5' & GGAAGCTTCTTGGATTGTCAAC & $\mathrm{F}$ & $16 \mathrm{~S}$ rDNA & 354-375 (AJ132250) \\
\hline PLANKTO-3' & CTGTCCCTCGAATTCTAGTAC & $\mathrm{R}$ & $16 \mathrm{~S}$ rDNA & 1171-1151 (AJ132250) \\
\hline
\end{tabular}

*Abbreviations: I, inosine; K, either G or T; M, either A or C; R, either A or G; W, either A or T; Y, either C or T.

$\dagger$ Direction indicates the primer orientation: forward $(F)$ or reverse $(R)$.

$\ddagger$ Position of the target site is given with respect to a relevant sequence deposited in the EMBL or GenBank databases.

Purification Kit (Boehringer Mannheim). To eliminate problems associated with base misincorporation during PCR amplification, at least five separate PCR reactions were pooled prior to purification. For reactions generating more than one product the purification procedure was modified to allow fragments of the desired size to be purified from low-meltingpoint agarose (Gibco-BRL). Binding buffer was added to the excised agarose $(300 \mu \mathrm{l}$ per $100 \mathrm{mg}$ agarose $)$ and the mixture was incubated at $56^{\circ} \mathrm{C}$, with occasional mixing, until the agarose had dissolved completely. 2-Propanol was added (150 $\mu \mathrm{l}$ per $100 \mathrm{mg}$ agarose), and the mixture was applied to the filter tube using the manufacturer's instructions. Purified PCR products were sequenced using an ABI Prism model 377 automated sequencer.

Some amplification products were cloned prior to sequencing. Following purification and restriction enzyme digestion, the PCR product was ligated to the plasmid vector pUC18, which was used to transform Escherichia coli strain DH5 $\alpha$ (Hanahan, 1983) to ampicillin resistance. Recombinant clones containing the desired insert were identified by single-colony PCR.
Plasmid DNA was prepared separately from at least five clones using the Wizard Miniprep DNA Purification Kit (Promega), and pooled prior to sequencing. All sequences were determined on both strands. Sequence analysis was performed using the Wisconsin Package version 9.1 (Genetics Computer Group).

Diagnostic PCR using DNA extracted from single filaments. Planktothrix filaments in 11 lakewater were collected on nitrocellulose filters of $50 \mathrm{~mm}$ diameter and $8 \mu \mathrm{m}$ pore size (Schleicher \& Schuell) and resuspended in $5 \mathrm{ml}$ filtered lakewater. Single filaments were transferred by Terumo microsyringe through three drops of sterile culture medium and finally one drop of sterile water to $25 \mu \mathrm{l} 2 \times$ SuperTaq buffer in a $0.5 \mathrm{ml}$ Eppendorf tube; one drop of mineral oil was added. The sample was heated to $94{ }^{\circ} \mathrm{C}$ for $5 \mathrm{~min}$ and stored at $-20^{\circ} \mathrm{C}$. The PCR was set up by addition of the other reagents (dNTPs, oligonucleotide primers, SuperTaq polymerase and water) to a total volume of $50 \mu$ l. Thermal cycling conditions were identical to those described in Table 2, except that an initial denaturing step of $10 \mathrm{~min}$ was used. 
Table 2. Thermal cycling conditions for the principal PCR amplifications

All reactions were subjected to an initial denaturation step of $94^{\circ} \mathrm{C}$ for 4 min and a final extension step of $72{ }^{\circ} \mathrm{C}$ for $5 \mathrm{~min}$.

\begin{tabular}{|c|c|c|}
\hline Locus & Primers & Reaction conditions \\
\hline$g v p A$ & GVPA-5' and GVPA-3' & $\begin{array}{l}4 \times\left(94{ }^{\circ} \mathrm{C}, 45 \mathrm{~s} ; 43{ }^{\circ} \mathrm{C}, 1 \mathrm{~min} ; 72{ }^{\circ} \mathrm{C}, 1 \mathrm{~min}\right. \\
\left.\left[\operatorname{ramp} 2 \mathrm{~s} \mathrm{per}{ }^{\circ} \mathrm{C}\right]\right), 25 \times\left(94{ }^{\circ} \mathrm{C}, 45 \mathrm{~s} ; 55^{\circ} \mathrm{C}\right. \\
\left.1 \mathrm{~min} ; 72{ }^{\circ} \mathrm{C}, 1 \mathrm{~min}\right)\end{array}$ \\
\hline$g v p A / C$ & GVPA1 and GVPA2 & $\begin{array}{l}4 \times\left(94{ }^{\circ} \mathrm{C}, 45 \mathrm{~s} ; 65^{\circ} \mathrm{C}, 1 \mathrm{~min} ; 72^{\circ} \mathrm{C}, 1 \mathrm{~min}\right), \\
25 \times\left(94^{\circ} \mathrm{C}, 45 \mathrm{~s} ; 70^{\circ} \mathrm{C}, 1 \mathrm{~min} ; 72^{\circ} \mathrm{C}, 1 \mathrm{~min}\right)\end{array}$ \\
\hline$g v p C$ & GVPC1 and GVPC5 & $\begin{array}{l}4 \times\left(94{ }^{\circ} \mathrm{C}, 45 \mathrm{~s} ; 59^{\circ} \mathrm{C}, 1 \mathrm{~min} ; 72^{\circ} \mathrm{C}, 1 \mathrm{~min}\right), \\
25 \times\left(94^{\circ} \mathrm{C}, 45 \mathrm{~s} ; 63^{\circ} \mathrm{C}, 1 \mathrm{~min} ; 72^{\circ} \mathrm{C}, 1 \mathrm{~min}\right)\end{array}$ \\
\hline среBA & $\mathrm{PE} \beta \mathrm{F}$ and $\mathrm{PE} \alpha \mathrm{R}$ & $\begin{array}{c}4 \times\left(94{ }^{\circ} \mathrm{C}, 45 \mathrm{~s} ; 50{ }^{\circ} \mathrm{C}, 1 \mathrm{~min} ; 72{ }^{\circ} \mathrm{C}, 1 \mathrm{~min}\right), \\
25 \times\left(94{ }^{\circ} \mathrm{C}, 45 \mathrm{~s} ; 55^{\circ} \mathrm{C}, 1 \mathrm{~min} ; 72^{\circ} \mathrm{C}, 1 \mathrm{~min}\right)\end{array}$ \\
\hline $\operatorname{cpcBA}$ & $\mathrm{PC} \beta \mathrm{F}$ and $\mathrm{PC} \alpha \mathrm{R}$ & $\begin{array}{l}4 \times\left(94{ }^{\circ} \mathrm{C}, 45 \mathrm{~s} ; 50{ }^{\circ} \mathrm{C}, 1 \mathrm{~min} ; 72{ }^{\circ} \mathrm{C}, 1 \mathrm{~min}\right), \\
25 \times\left(94^{\circ} \mathrm{C}, 45 \mathrm{~s} ; 55^{\circ} \mathrm{C}, 1 \mathrm{~min} ; 72^{\circ} \mathrm{C}, 1 \mathrm{~min}\right)\end{array}$ \\
\hline$c p c B A$ & $\mathrm{PC} \beta \mathrm{F}$ and $\mathrm{PC} \alpha \mathrm{R} 3$ & $\begin{array}{l}4 \times\left(94{ }^{\circ} \mathrm{C}, 45 \mathrm{~s} ; 47^{\circ} \mathrm{C}, 1 \mathrm{~min} ; 72^{\circ} \mathrm{C}, 1 \mathrm{~min}\right), \\
25 \times\left(94^{\circ} \mathrm{C}, 45 \mathrm{~s} ; 55^{\circ} \mathrm{C}, 1 \mathrm{~min} ; 72^{\circ} \mathrm{C}, 1 \mathrm{~min}\right)\end{array}$ \\
\hline $\operatorname{rbcLXS}$ & CYARUB-5' and CYARUB-3' & $\begin{array}{l}4 \times\left(94{ }^{\circ} \mathrm{C}, 45 \mathrm{~s} ; 50^{\circ} \mathrm{C}, 1 \mathrm{~min} ; 72^{\circ} \mathrm{C}, 1 \mathrm{~min}\right), \\
25 \times\left(94^{\circ} \mathrm{C}, 45 \mathrm{~s} ; 55^{\circ} \mathrm{C}, 1 \mathrm{~min} ; 72^{\circ} \mathrm{C}, 1 \mathrm{~min}\right)\end{array}$ \\
\hline $16 \mathrm{~S}$ rDNA & CYANO-5' and CYANO-3' & $25 \times\left(94{ }^{\circ} \mathrm{C}, 45 \mathrm{~s} ; 50^{\circ} \mathrm{C}, 1 \mathrm{~min} ; 72^{\circ} \mathrm{C}, 2 \mathrm{~min}\right)$ \\
\hline $16 \mathrm{~S}$ rDNA & CYANO-5' and PLANKTO-3' & $\begin{array}{l}4 \times\left(94{ }^{\circ} \mathrm{C}, 45 \mathrm{~s} ; 51^{\circ} \mathrm{C}, 1 \mathrm{~min} ; 72^{\circ} \mathrm{C}, 2 \mathrm{~min}\right), \\
25 \times\left(94^{\circ} \mathrm{C}, 45 \mathrm{~s} ; 57^{\circ} \mathrm{C}, 1 \mathrm{~min} ; 72^{\circ} \mathrm{C}, 2 \mathrm{~min}\right)\end{array}$ \\
\hline $16 \mathrm{~S}$ rDNA & PLANKTO-5' and CYANO-3' & $\begin{array}{l}4 \times\left(94{ }^{\circ} \mathrm{C}, 45 \mathrm{~s} ; 55^{\circ} \mathrm{C}, 1 \mathrm{~min} ; 72^{\circ} \mathrm{C}, 2 \mathrm{~min}\right), \\
25 \times\left(94^{\circ} \mathrm{C}, 45 \mathrm{~s} ; 59^{\circ} \mathrm{C}, 1 \mathrm{~min} ; 72^{\circ} \mathrm{C}, 2 \mathrm{~min}\right)\end{array}$ \\
\hline
\end{tabular}

\section{RESULTS}

\section{Gas vesicle genes, gvpA and $g v p C$}

Initially, universal $g \nu p A$ primers GVPA-5' and GVPA-3' (Table 1), whose sequences were based on conserved amino acid sequences in cyanobacterial GvpA, were used to amplify a $128 \mathrm{bp}$ segment within the gvpA of Pla 9303. Sequencing showed that the region between the primers encoded an amino acid sequence identical to residues 23-51 in GvpA of both the red (CYA 18) and green (CYA 29) strains of Planktothrix (Oscillatoria) agardhii (Griffiths et al., 1992).

Primers GVPA1 and GVPA2 (Table 1), homologous to sequences within gvpA and originally designed for inverse PCR, generated a $1064 \mathrm{bp}$ fragment when used in PCR with DNA from strain Pla 9303. Sequencing revealed a $516 \mathrm{bp}$ ORF between two adjacent copies of gvpA. The $5^{\prime}$ end of this ORF encodes an amino acid sequence showing homology to the $\mathrm{N}$-terminal amino acid sequence of GvpC from Planktothrix (Oscillatoria) agardhii CYA 29 (10 of the first 12 residues identical). This ORF was designated $g v p C^{20}$, the suffix denoting the $20 \mathrm{kDa}$ size of its inferred translation product $\mathrm{GvpC}^{20}$ (Fig. 1). This distinguishes it from a smaller homologous ORF, $g v p C^{16}$, found subsequently in other strains of Planktothrix. Primers GVPA1 and GVPA2 could be used in diagnostic PCR to distinguish the following three gas vesicle genotypes, which differed in the number of $g v p A$ and $g v p C$ genes, and in the sizes of the latter (Fig. 2a, Table 3).

Genotype GV1. In Pla 9303 evidence for the presence of a second $g \nu p C^{20}$ downstream of the second $g \nu p A$ was obtained by amplification of a 1059 bp segment by using the primers GVPC1 and GVPC6 (Table 1), homologous with sequences within $g v p C^{20}$. Sequencing showed that the product comprised a complete gvpA located between the $3^{\prime}$ end of one $g v p C^{20}$ and the $5^{\prime}$ end of a second $g v p C^{20}$. The sequences of the corresponding ORFs and spacers were identical to those in the amplification product obtained with the GVPA1 and GVPA2 primers, and indicated the gene arrangement shown in Fig. 3(a).

Genotype GV2. In Pla 9316 amplification with primers GVPA1 and GVPA2 generated products of 1064 and 595 bp (Fig. 2a). The 1064 bp product was very similar to that in Pla 9303 and indicated the same gvpA$g v p C^{20}-g v p A$ arrangement: subsequent studies revealed that this product is generated by two regions of the gvp gene cluster (Fig. 3b), which are probably identical.

The sequence of the $595 \mathrm{bp}$ product showed that between two copies of $g \nu p A$ there was a $72 \mathrm{bp}$ untranslated region (designated $\Omega C$ ) identical to the $3^{\prime}$ end of the $g \nu p C^{20}$ (Fig. 3b). The sequenced portions of the two gvpAs and the $\Omega C-g \nu p A$ spacer were identical to the corresponding regions in Pla 9303; in the gvpA- $\Omega C$ spacer, however, while 137 of the first $140 \mathrm{bp}$ were identical to the $g v p A-g v p C^{20}$ spacer, the last $17 \mathrm{bp}$ showed little similarity. Complementary primers

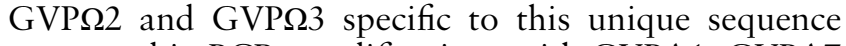
were used in PCR amplifications with GVPA1, GVPA7 and GVPC4 (Table 1, Fig. 3) to determine the gene arrangement shown in Fig. 3(b). The sequenced region revealed the gene order $g \nu p C^{20}, g \nu p A, \Omega C, g \nu p A$, 


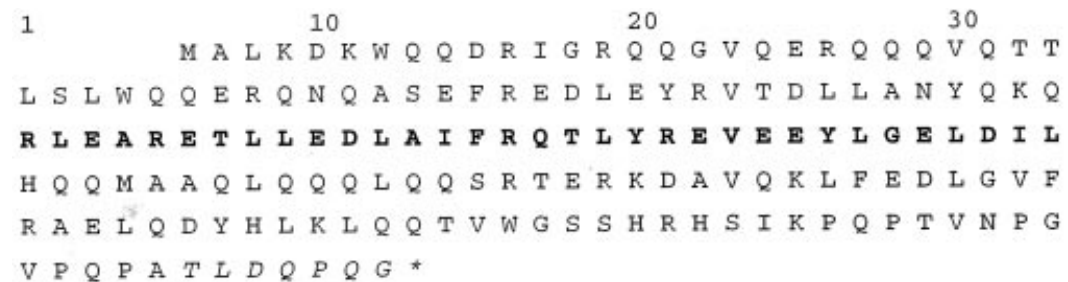

Fig. 1. Amino acid sequence of $\mathrm{GvpC}^{20}$ inferred from the nucleotide sequence obtained from Planktothrix rubescens strain Pla 9401. The sequence is arranged in rows of 33 amino acid residues in register with the central row (bold type) that is absent from $\mathrm{GvpC}^{16}$.

(a)

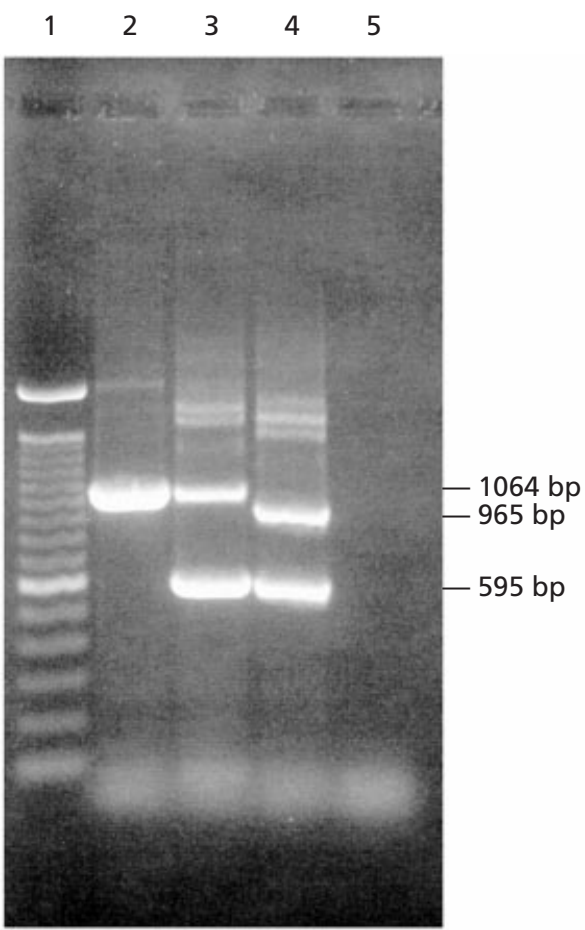

(b)

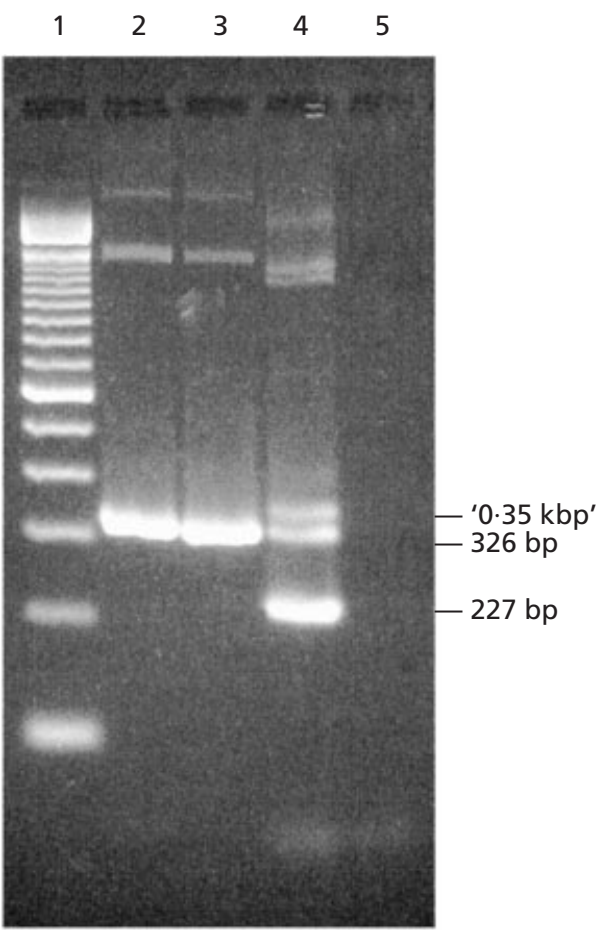

Fig. 2. Diagnostic PCR used to distinguish the different gas vesicle genotypes of Planktothrix rubescens. The products obtained by amplification with the primer pairs (a) GVPA1/GVPA2 and (b) GVPC1/GVPC5 were analysed by electrophoresis through agarose gels ( $1.5 \%$ and $2 \%, w / v$, respectively). Lanes: 1, 100 bp ladder (Life Technologies); 2, Pla 9303 (GV1); 3, Pla 9316 (GV2); 4, Pla 9401 (GV3); 5, no-template control.

Table 3. Summary of the arrangement of gvp genes in type strains of the different gas vesicle genotypes of Planktothrix rubescens, and the products of diagnostic PCRs used to distinguish them

+ , Product present.

\begin{tabular}{|c|c|c|c|c|c|c|c|}
\hline \multirow[t]{2}{*}{ Genotype } & \multirow[t]{2}{*}{$\begin{array}{l}\text { Type } \\
\text { strain }\end{array}$} & \multirow[t]{2}{*}{ gvp gene order } & \multicolumn{3}{|c|}{$\begin{array}{l}\text { GVPA1/GVPA2 } \\
\text { PCR product }(s) / \\
\text { bp }\end{array}$} & \multicolumn{2}{|c|}{$\begin{array}{c}\text { GVPC1/ } \\
\text { GVPC5 PCR } \\
\text { product(s)/ } \\
\text { bp }\end{array}$} \\
\hline & & & 595 & 965 & 1064 & 227 & 326 \\
\hline GV1 & Pla 9303 & $A-C^{20}-A-C^{20}$ & & & + & & + \\
\hline GV2a & Pla 9316 & $A-C^{20}-A-\Omega C-A-C^{20}-A-C^{20}$ & + & & + & & + \\
\hline GV2b & Pla 9731 & $A-C^{20}-A-\Omega C-A-\Omega C-A-C^{20}-A-C^{20}$ & + & & + & & + \\
\hline GV3a & Pla 9401 & $A-C^{16}-A-\Omega C-A-C^{16}-A-C^{16}-A-C^{20}$ & + & + & & + & + \\
\hline GV3b & Pla 9736 & $A-C^{16}-A-\Omega C-A-\Omega C-A-C^{16}-A-C^{16}-A-C^{20}$ & + & + & & + & + \\
\hline
\end{tabular}


(a) Pla 9303, GV1

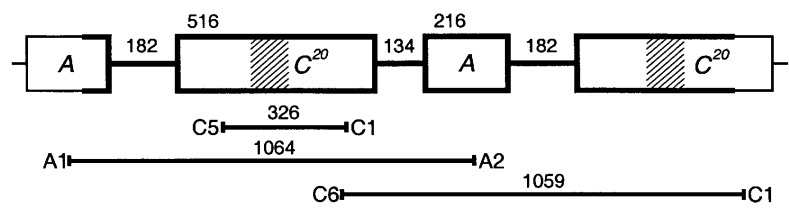

(b) Pla 9316, GV2

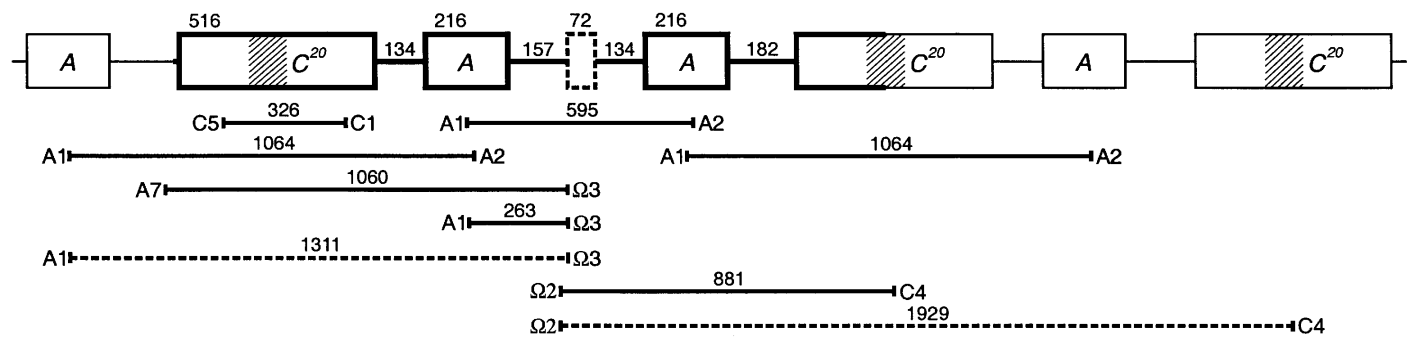

(c) Pla 9401, GV3

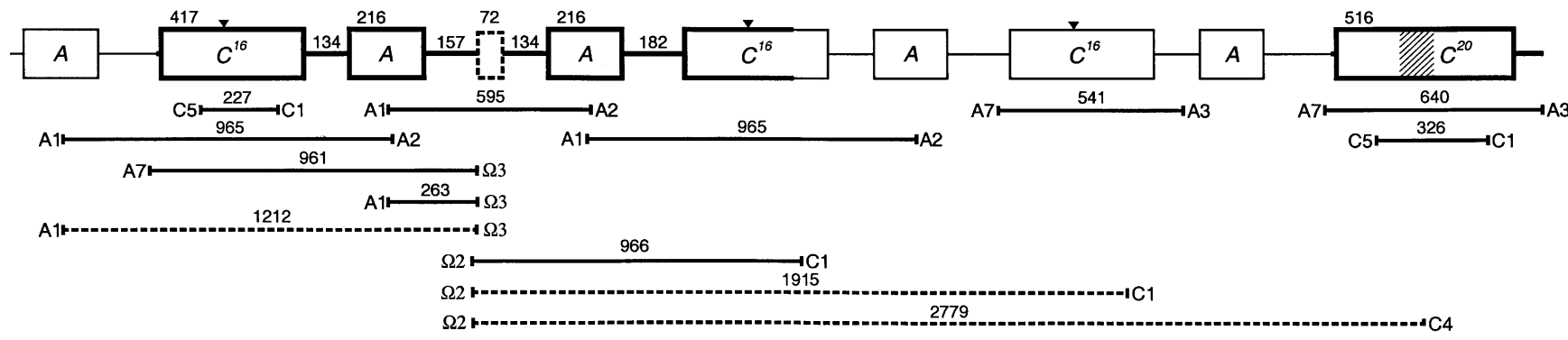

Fig. 3. Diagram representing the arrangement of gas vesicle genes gvpA and gvpC in Planktothrix rubescens strains (a) Pla 9303, (b) Pla 9316 and (c) Pla 9401. The boxed regions indicate open reading frames; the boxed regions composed of broken lines indicate the position of the untranslated $3^{\prime}$ end of $g v p C(\Omega C)$. The hatched area represents the $99 \mathrm{bp}$ segment present in $g v p C^{20}$, but absent in $g v p C^{16}$ (at the position indicated by $\boldsymbol{\nabla}$ ). The thicker lines represent regions that have been sequenced, and the thinner lines represent sections whose gene arrangement was inferred from the sizes of PCR products estimated from agarose gels. Lines underneath represent the products obtained by PCR using the primers indicated at each end (with the prefix GVP omitted). Broken lines indicate PCR products whose sequence has not been determined; the lengths given are those predicted from the lengths of the corresponding sequenced regions. The lengths of ORFs, intergenic regions and PCR products are given in bp.

$g v p C^{20}$. The only differences from the corresponding regions in Pla 9303 were two changes in the sequence of $g v p C^{20}(\mathrm{G} \rightarrow \mathrm{C}$ at nt 155 , encoding $\mathrm{Arg} \rightarrow \mathrm{Thr} ; \mathrm{T} \rightarrow \mathrm{C}$ at nt 448 , encoding Ser $\rightarrow$ Pro) and two substitutions in the gvpA-gvpC $C^{20}$ spacer.

Amplification between the primers GVP 22 and GVPC4 generated two products: the sequence of the smaller $881 \mathrm{bp}$ product (Fig. 3b) established the gvpA and $g v p C^{20}$ downstream of $\Omega C$; the larger $1.9 \mathrm{kbp}$ product indicated a second $g v p A$ and $g v p C^{20}$ downstream of this. Amplification between the primers GVP $\Omega 3$ and GVPA1 also generated two products, a smaller $263 \mathrm{bp}$ product and a larger $1.3 \mathrm{kbp}$ product, which indicated another gvpA upstream (Fig. 3b).

In another strain of genotype GV2 (Pla 9731), amplification between primers GVP 33 and GVPA1 generated an additional product of $0.85 \mathrm{kbp}$. The sequence of this product indicated two copies of $\Omega C$ in the gene arrangement $g v p A, \Omega C, g v p A, \Omega C$. The genotypes of strains Pla 9316 (one copy of $\Omega$ C) and Pla 9731 (two copies of $\Omega C$ ) are designated GV2a and GV2b, respectively (Table 3 ).

Genotype GV3. In Pla 9401 amplification with primers GVPA1 and GVPA2 generated products of 595 and $965 \mathrm{bp}$ (Fig. 2a). The $595 \mathrm{bp}$ product had the same sequence as that in Pla 9316, except for a single substitution in the $g v p A-\Omega C$ spacer. The 965 bp product contained a similar gene arrangement to that found in the 1064 bp product from Pla 9303 and Pla 9316 but the gvpC ORF lacked a $99 \mathrm{bp}$ segment (corresponding to nt 184-282 in $g v p C^{20}$ ). This smaller $g v p C$, which encodes a $16 \mathrm{kDa}$ protein of 139 amino acid residues, was designated $g v p C^{16}$. It showed only one other difference from $g v p C^{20}$ in Pla 9303, a change of $\mathrm{T} \rightarrow \mathrm{C}$ at the position corresponding to nt 448 in $g v p C^{20}$ (encoding a change of Ser $\rightarrow$ Pro).

A similar set of amplifications to those used with Pla 9316 gave products that supported the gene arrangement 
Table 4. Gas vesicle genotype identities of 186 strains of Planktothrix rubescens isolated from Lake Zürich, and held in the Bristol Collection

The full strain identities contain the prefix Pla, year (e.g. 93) and accession number for the year, e.g. Pla 9303. The year number is given for only the first of each group. CYA 1 was obtained from the NIVA Collection, Oslo.

\begin{tabular}{|c|c|c|c|c|c|}
\hline \multirow[t]{2}{*}{ Date of sampling } & \multicolumn{5}{|c|}{ Strains of gas vesicle genotype: } \\
\hline & GV1 & GV2a & GV2b & GV3a & GV3b \\
\hline 1958 (Staub, 1961) & CYA 1 & & & & \\
\hline 19 February 1993 & 9303, 07 & $9304,05,09,16$ & & 9301 & 9312 \\
\hline 30 August 1994 & & & & 9401 & 9402 \\
\hline 18 March 1997 & 9722 & $\begin{array}{l}9711,13,28,33,34,37 \\
39,40,44,50,52\end{array}$ & 9731 & 9709 & $\begin{array}{l}9701,03-08,10,12, \\
14-21,23-27,29 \\
30,32,35,36,38, \\
41-43,46-49,51, \\
53-57\end{array}$ \\
\hline 27 June 1997 & & $9758,60,62,64,66,67$ & & & $9759,61,63,65,68$ \\
\hline $\begin{array}{l}30 \text { September and } \\
2 \text { October } 1998\end{array}$ & & $\begin{array}{l}9772,79-81,83,85,87, \\
89,90,92,93,95, \\
98-100,102,103, \\
105-109,111,115,119, \\
120,122,124,125,127, \\
128,130,133,134,136, \\
138,139,143,149,151, \\
152,154,158,159,163, \\
165,168,169,171,173, \\
175\end{array}$ & & & $\begin{array}{l}9769,71,73-78,82, \\
84,86,88,91,94, \\
96,97,101,104, \\
110,112-114, \\
116-118,121,123, \\
126,129,131,132, \\
135,137,140-142, \\
144-148,150,153, \\
155-157,160-162, \\
164,166,167,170, \\
172,176-179\end{array}$ \\
\hline Total & 4 & 72 & 1 & 3 & 106 \\
\hline
\end{tabular}

shown in Fig. 3(c): it was the same as that in Pla 9316 but with three $g v p C^{16}$ s instead of the three $g v p C^{20}$ s. The two gvpA ORFs that were sequenced were identical to those in Pla 9303 and Pla 9316; the gvpA-gvpC and gvpCgvpA spacers were identical to those in Pla 9316. The sequenced regions of the first two $g v p C^{16}$ ORFs were identical.

In addition to $g v p C^{16}$, a copy of $g v p C^{20}$ was revealed by amplification with GVPA7 and GVPA3 (Table 1); the sequence of this $g v p C^{20}$ differed from that of $g v p C^{20}$ in Pla 9303 in only one position $(\mathrm{G} \rightarrow \mathrm{C}$ at nt 155 , encoding Arg $\rightarrow$ Thr). The location of this gene was determined by amplification between the GVP $\Omega 2$ site, which is unique to the $g v p A-\Omega C$ spacer, and the GVPC4 site, which is unique to the $99 \mathrm{bp}$ segment in $g v p C^{20}$.

With a similar set of amplifications to those used on Pla 9401 we determined the nucleotide sequence of gvpA, $g v p C^{16}$ and $g v p C^{20}$ in the GV3 strain Pla 9736, which was shown by Bright \& Walsby (1999) to possess the narrowest and strongest gas vesicles. The sequences of $g v p A$ and $g v p C^{16}$ were identical to those in Pla 9401, and the sequence of $g v p C^{20}$ differed in only one position ( $\mathrm{T}$ $\rightarrow$ C at nt 448, encoding Ser $\rightarrow$ Pro). Strain Pla 9736 was also shown to possess two copies of $\Omega C$ : amplification between primers GVP $\Omega 3$ and GVPA1 generated an additional product of $0.85 \mathrm{kbp}$, whose sequence indicated two copies of $\Omega C$ in the gene arrangement gvpA, $\Omega C, g v p A, \Omega C$. The genotypes of strains Pla 9401 (one copy of $\Omega C$ ) and Pla 9736 (two copies of $\Omega C$ ) are designated GV3a and GV3b, respectively (Table 3).

\section{Frequency of different GV genotypes in Lake Zürich}

The gas vesicle genotypes of clonal Planktothrix cultures, isolated from Lake Zürich water samples on various dates between 1993 and 1997, were determined from the lengths of the PCR products obtained with primers GVPA1 and GVPA2 (Fig. 2a). Of 187 cultures established over the whole period, 185 were clonal; of these, $3(2 \%)$ were of genotype GV1, 73 (39\%) were GV2 and 109 (59\%) were GV3 (Table 4). Two of the original cultures, Pla 9302 and Pla 9319, contained two genotypes. Strains of genotypes GV2 and GV3 were also screened for the presence of two copies of $\Omega C$ (diagnostic of GV2b and GV3b, respectively) by amplification with primers GVP 3 and GVPA1. Of the 73 strains of genotype GV2 only one (Pla 9731) contained two $\Omega$ Cs ; of the 109 strains of genotype GV3, however, 106 contained two $\Omega C$ s (Table 4). In the sets of cultures 
established at different sampling times the ratio of the different genotypes varied; no firm conclusions can be drawn from this because the method of collection was biased. For example, in March 1997 we selected filaments that remained buoyant in samples collected at depths exceeding $100 \mathrm{~m}$ in an attempt to obtain strains with stronger gas vesicles. We are currently investigating the proportions of GV genotypes by collecting much larger samples of single filaments for genotype analysis using PCR. It is worth commenting, however, on the apparent disappearance of genotype GV1: two out of the first 10 clonal cultures established in 1993 were GV1 whereas in the 1997 isolates only one out of 175 was of this genotype; moreover, a culture of Planktothrix rubescens established from a Lake Zürich water sample by Staub in 1958 (Staub, 1961), and maintained for 40 years as strain CYA 1 in the NIVA collection, is also of genotype GV1.

A second set of diagnostic PCR primers was designed to enable discrimination between those strains containing just $g v p C^{20}$, and those containing both $g v p C^{16}$ and $g v p C^{20}$. Primers GVPC1 and GVPC5 were used to amplify the central portion of both $g v p C^{16}$ and $g v p C^{20}$, generating products of 227 and 326 bp, respectively (Fig. $2 \mathrm{~b}$, Table 3). Amplification using these primers revealed that strains of genotypes GV1 and GV2 generated only the $227 \mathrm{bp}$ product, whereas those of GV3 generated both products. These results confirm that strains GV1 and GV2 contain only $g \nu p C^{20}$ whereas GV3 strains contain both $g \nu p C^{16}$ and $g v p C^{20}$.

Amplification with primers GVPC1 and GVPC5 generated an additional product which gave a band with a mobility indicating $0.35 \mathrm{kbp}$ when performed with DNA isolated from strains of the GV3 genotype (Fig. 2b). The smaller products, of 227 and $326 \mathrm{bp}$, were cloned into separate plasmids but the ' $0.35 \mathrm{kbp}$ ' product could not be cloned. When the plasmid containing the $227 \mathrm{bp}$ product was subjected to PCR amplification with the GVPC1 and GVPC5 primers, only a 227 bp product was obtained; similarly only a 326 bp product was given by the plasmid containing the 326 bp product (not shown). When both plasmids were mixed together, however, PCR gave the ' $0.35 \mathrm{kbp}$ ' product in addition to the two smaller products. It is concluded that the ' $0.35 \mathrm{kbp}$ ' product is a heteroduplex formed from the homologous sequences from the $g v p C^{16}$ and $g v p C^{20}$ genes.

\section{Ratio of GV genotypes in Lake Zürich water samples}

An investigation was made of the gas vesicle genotypes of Planktothrix filaments in water samples taken from a depth of $10 \mathrm{~m}$ in Lake Zürich on 30 September and 2 October 1997. From 40 separate filaments picked from the water sample, 26 clonal cultures were established. Diagnostic PCR using the GVPC1 and GVPC5 primers with DNA prepared from each culture showed that 13 $(50 \%)$ contained only gvp $C^{20}$ while 13 also contained $g v p C^{16}$. One hundred and thirty-three single filaments were transferred directly into $2 \times$ PCR buffer and used in subsequent diagnostic PCR : of the 106 single filaments that gave an amplification product, $57(54 \%)$ contained only $g v p C^{20}$ while $49(46 \%)$ also contained $g v p C^{16}$. The results obtained using the two methods were not significantly different $\left(\chi^{2}=0 \cdot 604, P=0 \cdot 44\right)$. An example of a gel used to distinguish the two genotypes in single filaments selected from a Lake Zürich lakewater sample is shown in Fig. 4.

\section{Sequences of other gene clusters}

In order to determine if the observed variation in GV genotype occurred within or between different Planktothrix species, the variation in DNA sequences of four other gene clusters was investigated: (a) 16S rRNA gene; (b) phycoerythrin $\beta$ and $\alpha$ subunit genes $(c p e B$ and $c p e A) ;(c)$ phycocyanin $\beta$ and $\alpha$ subunit genes $(c p c B$ and $c p c A)$; (d) Rubisco large and small subunit genes $(r b c L$ and $r b c S)$.

$16 \mathrm{~S}$ rRNA genes. The $16 \mathrm{~S}$ rRNA gene was amplified in two overlapping fragments from genomic DNA isolated from non-axenic cultures, using primers CYANO-5' and CYANO-3' (complementary to the $5^{\prime}$ and $3^{\prime}$ ends, respectively, of the $16 \mathrm{~S}$ rDNA of Synechococcus sp. PCC 6301; Table 1) in combination with two Planktothrixspecific primers. Primer PLANKTO-5' (Table 1) was used with CYANO-3' to amplify a 1128 bp region covering the $3^{\prime}$ end; primer PLANKTO- $3^{\prime}$ was used in combination with CYANO-5' to amplify a $1208 \mathrm{bp}$ region covering the $5^{\prime}$ end. The sequence of PLANKTO$5^{\prime}$ was based on that of primer CN described by Rudi et al. (1997). Primer PLANKTO-3' was designed on the basis of an alignment of the $16 \mathrm{~S}$ rDNA sequence of strain Pla 9402 with a number of other bacterial $16 \mathrm{~S}$ rDNA sequences. The region analysed corresponds to nt 28-1521 in the E. coli 16S rRNA gene sequence (EMBL accession no. J01695) of Brosius et al. (1978). The 16S rDNA sequences obtained from strains Pla 9303, 9316, 9401 and 9402 were identical, although there were ambiguities at one position in Pla 9303, and at at least four positions in Pla 9316, which may reflect sequence heterogeneity in multiple copies of the rDNA gene (von Wintzingerode et al., 1997). The best match is with the 16S rDNA sequence (EMBL accession no. X84811) from Planktothrix (Oscillatoria) agardhii strain CYA 18 (Nelissen et al., 1996): it differed in only two positions: $\mathrm{G} \rightarrow \mathrm{C}$ at base 1274, and an extra $\mathrm{C}$ after base 326 .

cpe $B-c p e A$ gene cluster. The primers $(\mathrm{PE} \beta \mathrm{F}$ and $\mathrm{PE} \alpha \mathrm{R}$; Table 1) used for the amplification of part of the operon encoding phycoerythrin were designed on the basis of an alignment of $c p e B$ and $c p e A$ sequences from Pseudanabaena sp. strain PCC 7409, Calothrix sp. strain PCC 7601 and Synechococcus sp. strain PCC 6701 (EMBL accession nos X63073, X04592 and M33812, respectively).

In all of the Planktothrix strains investigated, PCR amplification resulted in a single product of $517 \mathrm{bp}$. The sequence of the $471 \mathrm{bp}$ between the primers indicated: (a) the $310 \mathrm{bp}$ of the $3^{\prime}$ end of $c p e B$; (b) a $83 \mathrm{bp}$ noncoding region; (c) the first 78 bp of $c p e A$. Three sequence variants were identified: (1) PE1, which shows $72 \%$ 


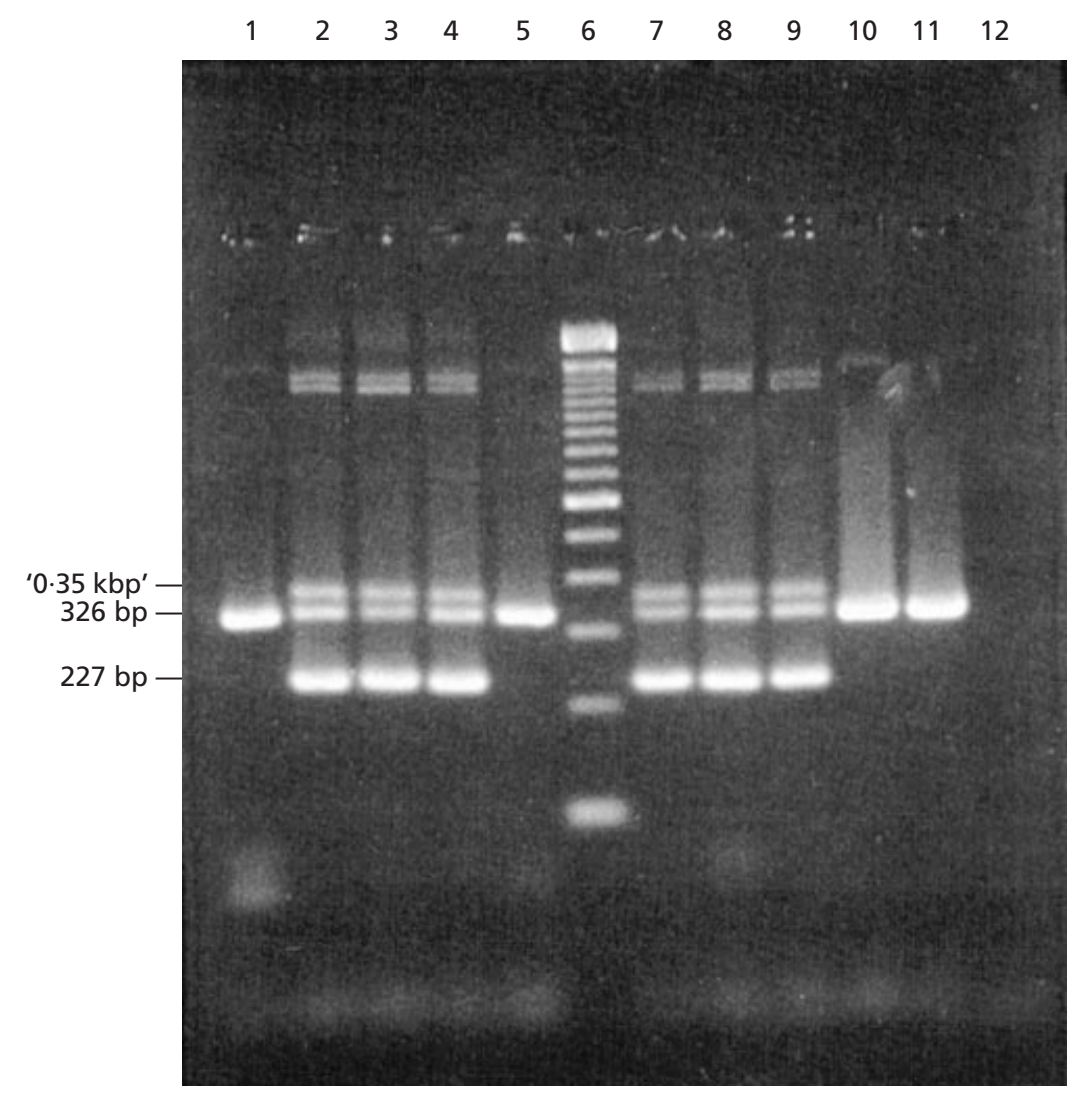

Fig. 4. Diagnostic PCR performed on single filaments of Planktothrix rubescens picked directly from Lake Zürich water samples. The products obtained by amplification with primers GVPC1 and GVPC5 were analysed by electrophoresis through a $2 \%(\mathrm{w} / \mathrm{v})$ agarose gel (lanes 1-5 and 7-11). Lane 6 contains a 100 bp ladder (Life Technologies); lane 12 contains a no-template control.

identity with part of the cpeBA operon from Pseudanabaena sp. strain PCC 7409 in the EMBL database; (2) PE2, which differed from PE1 in only one position $(\mathrm{C} \rightarrow$ $\mathrm{T}$, encoding $\mathrm{Thr} \rightarrow$ Ile at nt 240 ) in the $310 \mathrm{nt}$ sequence at the 3' end of $c p e B$; (3) PE3, which showed two additional differences $(\mathrm{G} \rightarrow \mathrm{A}$ encoding $\mathrm{Val} \rightarrow$ Ile at $\mathrm{nt}$ 167; $\mathrm{C} \rightarrow \mathrm{G}$, encoding Ala $\rightarrow$ Gly at nt 276) in the same $310 \mathrm{nt}$ sequence at the $3^{\prime}$ end of $c p e B$.

cpcB-cpcA gene cluster. The primers $(\mathrm{PC} \beta \mathrm{F}$ and $\mathrm{PC} \alpha \mathrm{R}$; Table 1) used for the amplification of part of the phycocyanin operon were those designed by Neilan et al. (1995). DNA polymorphisms identified previously within this operon (Neilan et al., 1995; Hayes \& Barker, 1997) indicated that this may be a useful genetic marker for distinguishing between cyanobacterial species.

In Planktothrix strain 9307, PCR amplification resulted in a 695 bp product. The sequence of the 655 bp between the primers indicated: (a) the $260 \mathrm{bp}$ of the $3^{\prime}$ end of $c p c B$; (b) a $101 \mathrm{bp}$ non-coding region; (c) the first $294 \mathrm{bp}$ of $c p c A$. The sequence showed $68 \%$ identity with part of the $c p c B A$ operon from Synechococcus sp. strain PCC 7002 (accession no. K02659). A Planktothrix-specific reverse primer $(\mathrm{PC} \alpha \mathrm{R} 3)$ was designed from the sequence obtained from strain Pla 9307 (complementary to nt $287-268$ in $c p e A)$. Amplification with primers PC $\beta F$ and $\mathrm{PC} \alpha \mathrm{R} 3$ (Table 1) generated a $668 \mathrm{bp}$ product from strains Pla 9303, 9316, 9401 and 9402. In each strain the sequence between the primers (628 bp) was identical to the corresponding sequence in Pla 9307.

$r b c L-r b c X-r b c S$ gene cluster. The primers used for the amplification of genes encoding Rubisco, CYARUB- $5^{\prime}$ and CYARUB-3', were designed on the basis of an alignment of $r b c L$ and $r b c S$ sequences from Synechococcus sp. PCC 7002, Prochlorothrix hollandica and Anabaena sp. PCC 7120 (EMBL accession nos D13971, X57359 and J01540, respectively).

In all of the Planktothrix strains investigated, PCR amplification resulted in a single product of $970 \mathrm{bp}$. The sequence of the $922 \mathrm{bp}$ between the primers indicated: (a) the $25 \mathrm{bp}$ of the $3^{\prime}$ end of $r b c L$; (b) a $131 \mathrm{bp}$ noncoding region; (c) a 402 bp ORF designated $r b c X$ (Rudi et al., 1998); (d) a 69 bp non-coding region; (e) the first $295 \mathrm{bp}$ of the $5^{\prime}$ end of $r b c S$. Three sequence variants were found: (1) RBC1, which differed at only one position, $T \rightarrow G$ at nt 64 in the first spacer, from the rbcLX sequence of Planktothrix rubescens CYA 55 (Rudi et al., 1998); (2) RBC2, which was identical to the Planktothrix CYA 55 sequence; (3) RBC3, which showed the same difference of $T \rightarrow G$ at position 64 in the first spacer, and an additional difference, $\mathrm{G} \rightarrow \mathrm{T}$ at position 247 in $r b c X$. This sequence variant was obtained by Rudi et al. (1998) in Planktothrix strain CYA 1 (Staub, 1961).

\section{DISCUSSION}

\section{Genetic diversity and species classification}

Comparison of the rRNA sequences of the Lake Zürich strains of cyanobacteria investigated here with published rRNA sequences from strains of Planktothrix isolated 
Table 5. Summary of the genotypic variation associated with the gene clusters investigated, and EMBL database accession numbers

The genotypes were identified from nucleotide sequences except for those in parentheses, which were inferred from diagnostic PCRs using primer pairs GVPA1/GVPA2 and GVPA1/GVPR3. -, Nucleotide sequence not determined.

\begin{tabular}{|c|c|c|c|c|c|c|c|c|c|c|}
\hline \multirow[t]{2}{*}{ Strain } & \multicolumn{5}{|c|}{ Genotype } & \multicolumn{5}{|c|}{ EMBL accession no. } \\
\hline & GV & PE & PC & $\mathrm{RBC}$ & $16 \mathrm{~S}$ rDNA & $g v p A C$ & среB $A$ & $c p c B A$ & $r b c L X S$ & $16 \mathrm{~S}$ rDNA \\
\hline 9303 & 1 & 1 & 1 & 1 & 1 & AJ132357 & AJ132245 & AJ132279 & AJ132248 & AJ132251 \\
\hline 9307 & $(1)$ & 1 & 1 & 1 & - & - & AJ132245 & AJ131820 & AJ132248 & - \\
\hline 9316 & $2 \mathrm{a}$ & 2 & 1 & 2 & 1 & AJ132358 & AJ132246 & AJ132279 & AJ132249 & AJ132252 \\
\hline 9401 & $3 a$ & 1 & 1 & 2 & 1 & $\begin{array}{l}\text { AJ132354 } \\
\text { AJ132361 }\end{array}$ & AJ132245 & AJ132279 & AJ132249 & AJ132250 \\
\hline 9402 & $(3 b)$ & 1 & 1 & 2 & 1 & - & AJ132245 & AJ132279 & AJ132249 & AJ132250 \\
\hline 9736 & $3 b$ & 3 & - & - & - & $\begin{array}{l}\text { AJ238351 } \\
\text { AJ23852 } \\
\text { AJ23853 }\end{array}$ & AJ132247 & - & - & - \\
\hline 9743 & $(3 b)$ & 2 & - & - & - & - & AJ132246 & - & - & - \\
\hline
\end{tabular}

from Norwegian lakes (Walsby et al., 1983; Utkilen et al., 1985) confirms that these organisms form a tight clade, separate from other species of Oscillatoria (Rudi et al., 1997, 1998). We therefore support the suggestion of Anagnostides \& Komárek (1988) that these planktonic forms should be separated into the genus Planktothrix, but we maintain the specific epithet, $P$. rubescens, used in previous description of this population in Lake Zürich (Thomas \& Märki, 1949; Walsby et al., 1998).

Our investigation of the DNA sequences of the rDNA, $c p e, c p c$ and $r b c$ gene loci revealed little or no difference in the seven strains of Planktothrix investigated (Table $5)$. In each case the variation was limited to changes in three or fewer bases in the 471-1443 bp sequenced. This very low degree of variability indicates that the seven strains are members of the same species and of the same population within the lake. It is noted that the three variants of the cpe gene cluster (PE1, PE2 and PE3) occur in combination with one of the gup genotypes (GV3), and that two of the variants each occur in combination with two of the gvp variants (PE1 with GV1 and GV3; PE2 with GV2 and GV3). It is therefore possible that there has been lateral transfer of genetic information between strains, as suggested by Rudi et al. (1998).

The only apparent exception in the degree of genetic diversity is with the sequences of the gvpC ORFs. It is noted first, however, that the number of single-base differences between the three $\mathrm{GV}$ genotypes, only one to four over the $g v p A-g v p C$ repeat, is similar in frequency to that of the other four gene loci. Moreover, although the other differences involve larger changes, all of them can be explained by single genetic events : the duplication of $g \nu p A-g \nu p C$ repeats; the loss of 99 nt elements from $g v p C^{20}$ to generate $g v p C^{16}$; and the loss of the $\mathrm{N}$ terminus of $g v p C$ to leave the $\Omega C$ fragment. The role of $\Omega C$ is unknown, but we suggest that the other genetic rearrangements have been maintained in the population because they produce a change in the phenotype that is subjected to positive natural selection.

\section{The gvp gene arrangements}

Homologies with gvpA and gvpC sequences in other cyanobacteria. The gvp gene clusters in the three strains of Planktothrix investigated resemble those of other cyanobacteria in the occurrence of multiple copies of $g v p A$, but differ in possessing multiple copies of $g v p C$ and in the alternating arrangement of $g \nu p A$ and $g \nu p C$.

The sequence of $g \nu p A$ is perfectly conserved in all of the Lake Zürich strains of Planktothrix rubescens. The inferred amino acid sequence is identical over the corresponding regions to the $\mathrm{N}$-terminal amino acid sequences of GvpAs from both the red (first 46 residues) and green (58 residues) variants of Planktothrix (Oscillatoria) agardhii isolated from Lake Gjersjøen in Norway. Of GvpA sequences in other cyanobacteria it most closely resembles that in Pseudanabaena sp. (Damerval et al., 1991): both depart from the GvpA consensus sequence in having $\mathrm{Val}$ at residue 5 , Ser at 40 and Ala at 64, and in having 71 rather than 70 residues; the Planktothrix sequence differs from the Pseudanabaena sequence, however, in three of the last seven residues (cf. Griffiths et al., 1992).

The degree of sequence similarity of GvpCs in cyanobacteria is much lower than that of GvpA (Griffiths et al., 1992). The homology of the inferred N-terminal amino acid sequence of the GvpC in the Planktothrix strains with the directly determined amino acid sequence of GvpC in Planktothrix (Oscillatoria) agardhii CYA 29 confirms the identities of the $g \nu p C$ genes in the Lake Zürich isolates. We discuss below their sequence variation, the occurrence of internal sequence repeats and the occurrence of multiple copies of $g \nu p C$ in other organisms. 
Cryptic and overt 33RRs in gvpC. Since $g v p C^{16}$ differs from gvp $C^{20}$ only in the absence of a 99 bp section it may have originated from $g v p C^{20}$ by gene duplication followed by deletion of the $99 \mathrm{bp}$ section. There is no other instance of this known in cyanobacteria but in Dactylococcopsis salina gas vesicles it was demonstrated that there are two types of GvpC, whose N-terminal amino acid sequence is identical over the first 24 residues but shows little similarity over the following 30 residues (Griffiths et al., 1992). This might also be explained by the deletion of a section of the encoding gene.

No repeating elements were immediately apparent in either the nucleotide sequence of the gupCs from the Planktothrix strains or the encoded amino acid sequences of the GvpC products. Nevertheless, it is significant that $g v p C^{16}$ and $g v p C^{20}$ differ by a $99 \mathrm{bp}$ segment, which is identical to the length of the repeating elements that encodes the 33RRs in GvpCs of Calothrix (Damerval et al., 1987) and Anabaena (Hayes et al., 1988). When the amino acid sequence is arranged in 33residue rows (aligned in Fig. 1 with the 33-residue sequence that is present in $\mathrm{GvpC}^{20}$ but missing from the $\mathrm{GvpC}^{16}$ ) significant similarity is seen in vertical columns. We used pair-scoring logic to compare the number of identical residues at the five positions in each column: two identical scores 2 for 1 pair; three identical scores 6 for 3 pairs; four identical scores 12 for 6 pairs. The mean score for each column is $2 \cdot 5$; the scores for arrangements in rows of $31,32,34$ and 35 residues are all between $1 \cdot 4$ and 1.6. A similar analysis performed on the standard simplified classification of amino acids (given by the 'Simplify' function in the Wisconsin package) gives scores of 6.5 for arrangements of 33 residues per row and between 4.1 and 4.6 for rows of $31,32,34$ and 35 residues. These analyses suggest that there may be cryptic functional 33RRs in GvpCs of Planktothrix.

\section{Correlation between GV genotypes and gas vesicle $p_{c}$ phenotypes}

The companion study (Bright \& Walsby, 1999) describes the $p_{\mathrm{c}}$ distribution of the gas vesicles in 81 of the 185 clonal Planktothrix strains isolated from Lake Zürich. It demonstrates that the mean $p_{\mathrm{c}}$ of all genotype GV2 strains is less than $1.0 \mathrm{MPa}$ while that of all genotype GV3 strains exceeds $1.0 \mathrm{MPa}$. (The few GV1 strains isolated have $p_{\mathrm{c}}$ values close to the $1.0 \mathrm{MPa}$ borderline.) The strong correlation between $g v p C$ variants and $p_{\mathrm{c}}$ suggests, but does not prove, that the observed differences in the combinations of $g v p C$ genes in Planktothrix rubescens may be causative of the associated gas vesicle phenotypes. Whether or not they directly determine gas vesicle phenotype it is clear that they provide a valuable marker for gas vesicle strength or width.

\section{Population studies of gvp genes}

With the development of a system of primers capable of distinguishing the two classes of $g \nu p C$ genotypes that are correlated with strong and weak gas vesicle pheno- types we can now use diagnostic PCR to investigate the proportion of the two strains present at different periods of the year. This method provides several advantages over the alternative method of isolating single filaments in culture and then measuring the $p_{\mathrm{c}}$ of their gas vesicles: (1) it involves fewer laboratory resources, fewer manipulations and less time; (2) it can be performed on many more filaments per sample (with filaments stored frozen for subsequent analysis) compared with the number that can be isolated into culture; (3) with a success rate of 80-95\% (our unpublished results) it is less susceptible to sampling bias than the $44 \%$ establishment rate of single filament cultures.

It has been suggested that there is natural selection for strains of Planktothrix rubescens with strong gas vesicles during the vernal recruitment to the metalimnion in Lake Zürich, when only the buoyant filaments float up from great depths after winter mixing (Walsby et al., 1998). We are currently using diagnostic PCR to investigate changes in the proportions of the different GV genotypes in this Planktothrix population, in order to quantify the process of natural selection of different gas vesicle phenotypes that occurs in this lake.

\section{ACKNOWLEDGEMENTS}

We are grateful to Dr Ferdinand Schanz for collecting Lake Zürich samples, Mrs Annette Richer for maintaining cultures, Dr Débora Iglesias-Rodríguez for DNA isolation and Dr Susan Ring for useful suggestions concerning heteroduplex formation. This work was supported by grant GR3/10970 from the Natural Environment Research Council.

\section{REFERENCES}

Anagnostides, K. \& Komárek, J. (1988). Modern approaches to the classification system of cyanophytes. 3 - Oscillatoriales. Arch Hydrobiol 80, 327-472.

Bright, D. I. \& Walsby, A. E. (1999). The relationship between critical pressure and width of gas vesicles in isolates of Planktothrix rubescens from Lake Zürich. Microbiology 145, 2769-2775.

Brosius, J., Palmer, M. L., Kennedy, P. J. \& Noller, H. F. (1978). Complete nucleotide sequence of a $16 \mathrm{~S}$ ribosomal RNA gene from Escherichia coli. Proc Natl Acad Sci USA 75, 4801-4805.

Buchholz, B. E. E., Walsby, A. E. \& Hayes, P. K. (1993). The distribution of the outer gas vesicle protein, GvpC, on the Anabaena gas vesicle and its ratio to GvpA. J Gen Microbiol 139, 2353-2363.

Damerval, T., Houmard, J., Guglielmi, G., Csiszàr, K. \& Tandeau de Marsac, N. (1987). A developmentally regulated gvpABC operon is involved in the formation of gas vesicles in the cyanobacterium Calothrix 7601. Gene 54, 83-92.

Damerval, T., Castets, A.-M., Houmard, J. \& Tandeau de Marsac, N. (1991). Gas vesicle synthesis in the cyanobacterium Pseudanabaena sp.: occurrence of a single photoregulated gene. Mol Microbiol 5, 657-664.

DasSarma, S., Arora, P., Lin, F., Molinari, E. \& Yin, L. R.-S. (1994). Wild-type gas vesicle formation requires at least ten genes in the gvp gene cluster of Halobacterium halobium plasmid pNRC100. J Bacteriol 176, 7646-7652.

Griffiths, A. E., Walsby, A. E. \& Hayes, P. K. (1992). The homologies of gas vesicle proteins. J Gen Microbiol 138, 1243-1250. 
Hanahan, D. (1983). Studies on transformation of Escherichia coli with plasmids. J Mol Biol 166, 557-580.

Hayes, P. K. \& Barker, G. L. A. (1997). Genetic diversity within Baltic Sea populations of Nodularia (Cyanobacteria). J Phycol 33, 919-923.

Hayes, P. K. \& Powell, R. S. (1995). The $g v p A / C$ cluster of Anabaena flos-aquae has multiple copies of a gene encoding GvpA. Arch Microbiol 164, 50-57.

Hayes, P. K., Lazarus, C. M., Bees, A., Walker, J. E. \& Walsby, A. E. (1988). The protein encoded by $g v p C$ is a minor component of gas vesicles isolated from the cyanobacteria Anabaena flosaquae and Microcystis sp. Mol Microbiol 2, 545-552.

Hayes, P. K., Buchholz, B. \& Walsby, A. E. (1992). Gas vesicles are strengthened by the outer-surface protein, GvpC. Arch Microbiol 157, 229-234.

Horne, M., Englert, C., Wimmer, C. \& Pfeifer, F. (1991). A DNA region of $9 \mathrm{kbp}$ contains all genes necessary for gas vesicle synthesis in halophilic archaebacteria. Mol Microbiol 5, 1159-1174.

Jones, J. G., Young, D. C. \& DasSarma, S. (1991). Structure and organization of the gas vesicle gene cluster on the Halobacterium halobium plasmid pNCR100. Gene 102, 1017-1022.

Kinsman, R., Walsby, A. E. \& Hayes, P. K, (1995). GvpCs with reduced numbers of repeating sequence elements bind to and strengthen cyanobacterial gas vesicles. Mol Microbiol 17, $147-154$

Lehmann, H. \& Jost, M. (1971). Kinetics of the assembly of gas vacuoles in the blue-green alga Microcystis aeruginosa Kuetz. emend. Elekin. Arch Microbiol 79, 59-68.

Neilan, B. A., Jacobs, D. \& Goodman, A. E. (1995). Genetic diversity and phylogeny of toxic cyanobacteria determined by DNA polymorphisms within the phycocyanin locus. Appl Environ Microbiol 61, 3875-3883.

Nelissen, B., De Baere, R., Wilmotte, A. \& De Wachter, R. (1996). Phylogenetic relationships of nonaxenic filamentous cyanobacterial strains based on $16 \mathrm{~S}$ rRNA sequence analysis. $J \mathrm{Mol}$ Evol 42, 194-200.

Offner, S., Wanner, G. \& Pfeifer, F. (1996). Functional studies of the gvpACNO operon of Halobacterium salinarium reveal that the GvpC protein shapes gas vesicles. J Bacteriol 178, 2071-2078.

Rudi, K., Skulberg, O. M., Larsen, F. \& Jakobsen, K. S. (1997). Strain characterization and classification of oxyphotobacteria in clone cultures on the basis of $16 \mathrm{~S}$ rRNA sequences from the variable regions V6, V7, and V8. Appl Environ Microbiol 63, 2593-2599.

Rudi, K., Skulberg, O. M. \& Jakobsen, K. S. (1998). Evolution of cyanobacteria by exchange of genetic material among phyletically related strains. J Bacteriol 180, 3453-3461.

Sambrook, J., Fritsch, E. F. \& Maniatis, T. (1989). Molecular Cloning: a Laboratory Manual, 2nd edn. Cold Spring Harbor, NY : Cold Spring Harbor Laboratory.

Staub, R. (1961). Ernährungsphysiologisch-autökologische Untersuchungen an der planktischen Blaualge Oscillatoria rubescens D. C. Schweiz Z Hydrol 23, 84-198.

Thomas, E. A. \& Märki, E. (1949). Der heutige Zustand des Zürichsees. Mitt Int Ver Limnol 10, 476-488.

Utkilen, H. C., Skulberg, O. M. \& Walsby, A. E. (1985). Buoyancy regulation and chromatic adaptation in planktonic Oscillatoria species: alternative strategies for optimising light absorption in stratified lakes. Arch Hydrobiol 104, 407-417.

Waaland, J. R., \& Branton, D. (1969). Gas vacuole development in a blue-green alga. Science 163, 1339-1341.

Walsby, A. E. (1982). The elastic compressibility of gas vesicles. Proc R Soc Lond Ser B 216, 355-368.

Walsby, A. E. (1991). The mechanical properties of the Microcystis gas vesicle. J Gen Microbiol 137, 2401-2408.

Walsby A. E. (1994). Gas vesicles. Microbiol Rev 58, 94-114.

Walsby, A. E. \& Hayes, P. K. (1988). The minor cyanobacterial gas vesicle protein, GVPc, is attached to the outer surface of the gas vesicle. J Gen Microbiol 134, 2647-2657.

Walsby, A. E., Utkilen, H. C. \& Johnsen, I. J. (1983). Buoyancy changes of a red coloured Oscillatoria agardhii in Lake Gjersjøen, Norway. Arch Hydrobiol 97, 18-38.

Walsby, A. E., Avery, A. \& Schanz, F. (1998). The critical pressures of gas vesicles in Planktothrix rubescens in relation to the depth of winter mixing in Lake Zürich, Switzerland. J Plankton Res 20, 1357-1375.

von Wintzingerode, F., Göbel, U. B. \& Stackebrandt, E. (1997). Determination of microbial diversity in environmental samples: pitfalls of PCR-based rRNA analysis. FEMS Microbiol Rev 21, 213-229.

Received 26 January 1999; revised 5 May 1999; accepted 14 May 1999 